children attended the same hospital school, once continence had been acquired by a few a competitive spirit developed in others. In some, particularly those who found the technique difficult to start with, success was due in part to the advice and support of their peers.

Poor motivation was due mainly to the intervention of other factors. One boy could not bring himself to trust fully the technique, having acquired dryness when using a sheath. In the others lack of success was attributable to a continued need to show dependency or, less passively, wetness was used as a weapon in an already disturbed family.

Intermittent catheterisation can therefore be successfully achieved by children with moderate mental handicap even if there is severe physical disability.
With the exception of certain specific anatomical deformities the reasons for continued success (or conversely for failure) can generally be found on examination of all circumstances of the child and his reaction to them.

\footnotetext{
References

1 Borzyskowski M, Mundy AR, Neville BGR, et al. The conservative management of vesico-urethral dysfunction in children: a trial comparing clean intermittent catheterisation with manual expression combined with drug treatment. $\mathrm{Br} J$ Urol 1982;54:641-4.
}

Correspondence to Dr Richard O Robinson. Chailey Heritage, Chailey, Newick, Sussex.

Received 2 April 1985

\title{
Alcohol intoxication, an underdiagnosed problem?
}

\section{J B MALCOLM, B BENJAMIN, A L SORBIE, AND I A AUCHTERLONIE}

Department of Child Health, University of Aberdeen

SUMmary To show that alcohol intoxication may be underdiagnosed in childhood, we describe four patients in whom it was not suspected until blood alcohol concentrations were measured as part of a toxicology screen.

The true incidence of alcohol intoxication in childhood is uncertain and it has been suggested that published reports may underestimate its frequency. ${ }^{1}$ We describe our recent experience with four patients to show that alcohol intoxication may indeed be underdiagnosed in children admitted to hospital.

\section{Patients and method}

Between January 1983 and February 1984, eight children aged 12 years or less were admitted to paediatric wards in Aberdeen with acute alcohol intoxication. Serum toxicological screening for barbiturates, benzodiazepines, tricyclates, salicylates, and paracetamol was performed where indicated. Serum alcohol was measured by gas chromatography. ${ }^{2}$ In four children alcohol intoxication was suspected from history and examination.

\section{Case reports}

Case 1. A 2 year old boy, staying with his grand- parents, was referred with an 18 hour history of diarrhoea and vomiting followed by diminished consciousness. He had been given no medication, and the possibility of alcohol ingestion was denied. He was drowsy but responded to verbal commands. No alcohol related smell was detected on his breath. His temperature was $36^{\circ} \mathrm{C}$. The serum alcohol concentration was $10.9 \mathrm{mmol} / \mathrm{l}$ and plasma glucose was $2 \cdot 0 \mathrm{mmol} / \mathrm{l}$. The source of the alcohol was not determined.

Case 2. A 10 year old boy was heard calling from the bath. He was found drowsy, confused, and 'frothing at the mouth'. He vomited five times over the next three hours and was admitted to hospital. He was drowsy but responded to commands. The possibility of alcohol or drug ingestion was denied. There was a bruise over his right eye and a 'smell of sweet apples' on his breath. He had generalised hypotonia. His temperature was $36 \cdot 2^{\circ} \mathrm{C}$. His serum alcohol concentration was $23.7 \mathrm{mmol} / \mathrm{l}$ and plasma glucose was 3.6 $\mathrm{mmol} / \mathrm{l}$. Despite the laboratory result he continued to deny any alcohol ingestion.

Case 3. A 12 year old girl was found unconscious in the street. She was drowsy but responded to verbal commands. There were abrasions on her face and scalp, but no alcohol related smell was detected on her breath. Axillary temperature was $34 \cdot 8^{\circ} \mathrm{C}$. A toxicology screen was negative. Her serum alcohol concentration was $51.0 \mathrm{mmol} / \mathrm{l}$ and plasma glucose 
was $7 \cdot(0 \mathrm{mmol} / \mathrm{l}$. The following morning she admitted to having drunk a cocktail of alcoholic beverages before the episode.

Case 4. A 12 year old girl was admitted with a three hour history of vomiting followed by loss of consciousness. The possibility of alcohol or drug ingestion was denied. She was drowsy but responded to verbal commands. No alcohol related smell was detected on her breath. Her axillary temperature was $35 \cdot 1{ }^{\circ} \mathrm{C}$. A toxicology screen was negative. Her serum alcohol concentration was $44.5 \mathrm{mmol} / \mathrm{l}$ and plasma glucose was $5.7 \mathrm{mmol} / \mathrm{l}$. After the laboratory results were available she admitted to having drunk a 'small gin and tonic' with friends.

\section{Discussion}

Our experience shows the importance of considering alcohol intoxication in children with unexplained drowsiness, hypoglycaemia, or hypothermia. The mode of presentation may be confused with other conditions such as head injury or post-ictal state. It was characteristic that parents were often reluctant to admit even the possibility of alcohol ingestion by their children, who in turn rarely volunteered the information. Detection of an alcohol related smell on the breath was an unreliable sign and emphasises the value of blood alcohol measurements. The importance of diagnosis arises from the potentially serious complication of alcohol induced hypoglycaemia ${ }^{3}$ and the necessity to monitor blood glucose concentrations. In adults the blood alcohol concentration is also a guide to the severity of the intoxication, values over $30 \mathrm{mmol} / \mathrm{l}$ being associated with increasing confusion while concentrations greater than $85 \mathrm{mmol} / \mathrm{l}$ may be fatal. ${ }^{+}$It is uncertain, however, whether these adult blood concentrations have the same clinical importance in children, where age related variations in alcohol susceptibility and metabolic clearance may occur. ${ }^{5}$

In our patients alcoholic beverages were the most commonly identified source of ethanol. The American Academy of Pediatrics Committee on Drugs, however, has recently emphasised the potentially toxic concentrations of ethanol in some paediatric pharmaceutical preparations. ${ }^{6}$ In the United Kingdom alcohol is used similarly in many paediatric preparations-for example paracetamol elixir BP contains $10 \% \mathrm{v} / \mathrm{v}$ and chlorpheniramine elixir BP $6.3 \% \mathrm{v} / \mathrm{v}$. Although the harmful effect of ethanol in these concentrations remains to be established it could have an additive effect in fasting related hypoglycaemia or cause problems in accidental ingestion if its presence went unrecognised.

\section{References \\ ${ }^{1}$ Le Conte M. Saint-Jacques I, Cagnat R, Vellieux F, Bois- siere H. Le coma alcoolique par intoxication accidentelle chez l'enfant. Sem Hop Paris 1978:54:315-24. \\ 2 Curry AS. Walker GW, Simpson GS. Determination of ethanol in blood by gas chromatography. Analyst 1966;91:742-3. \\ "MacLaren NK. Valman HB, Levin B. Alcohol-induced hypo- glycacmia in childhood. Br Med J 1970;1:278-80. \\ 4 Johnson RA, Noll EC. Rodney WM. Survival after a serum ethanol concentration of $1 \frac{1}{2} \%$. Lancet 1982;ii: 1394 . \\ 5 Ragan FA. Samuels MS, Hite SA. Ethanol ingestion in child:en. A five year review. JAMA 1979;242:2787-8. \\ - Pruitt AW. Anyan WR, Hill RM, et al. American Academy of Pediatrics Committee on Drugs. Ethanol in liquid preparations} intended for children. Pediatrics 1984;73:405-7.

Correspondence to Dr I A Auchterlonie, Raeden Centre, Midstocket Road, Aberdeen AB2 4PE.

Received 13 March 1985

\section{Hypertrichosis due to primary hypothyroidism}

S R STERN AND C J H KELNAR

Royal Hospital for Sick Children, Edinburgh

SUMmARY A 10 year old girl with hypertrichosis associated with primary hypothyroidism that resolved after 6 months' replacement treatment with thyroxine is reported. It is important to consider the diagnosis of hypothyroidism in children with abnormal hairiness or distribution of body hair.
Hypertrichosis and hirsutism are common reasons for seeking medical advice, particularly in young women. Only a small proportion of subjects have a diagnosable condition, and treatment is often unsatisfactory, especially in childhood. ${ }^{1}$ Hypothyroidism is usually associated with loss of hair. ${ }^{2}$ We report a 10 year old girl whose hypertrichosis was associated with primary hypothyroidism and re- 